\title{
Jewish Heroes in Film Adaptations by Director Ján Kadár
}

\author{
Štefan Timko (Nitra)
}

\begin{abstract}
Director Ján Kadár (1918-1979) in his films portrayed national, cultural and social diversity not only as a generator of interpersonal conflicts, but often also as an inspiring environment. Kadár's fascination with the heterogeneous cultural environment is closely connected with his fate, a Jew growing up in a Hungarian-Slovak environment, whose life experience was significantly influenced by anti-Semitism and the Holocaust. The study aims to focus on the interpretation of character of Jewish heroes in Kadár's work with a focus on his three film adaptations - the Czech-Slovak film Obchod na korze [The Shop on Main Street] (1965) based on Ladislav Grosman, the American film Angel Levine (1970) based on a short story by Bernard Malamud and the Canadian film Lies my Father Told Me, which was based on a short story by Ted Allan. In addition to comparison of the mentioned film adaptations with literary works, the study will also focus on Kadár's legacy for contemporary filmmaking and contemporary film audiences.
\end{abstract}

\section{Key words}

Ján Kadár; film director; Jewish heroes; multicultural society

\section{Abstrakt \\ Židovskí hrdinovia vo filmových adaptáciách režiséra Jána Kadára}

Režisér Ján Kadár (1918-1979) vo svojich filmoch vykresl'oval národnú, kultúrnu i spoločenskú diverzitu nielen ako generátor medzil'udských konfliktov, ale aj ako inšpiratívne prostredie. Kadárova fascinácia kultúrne heterogénnymi lokalitami vychádza z jeho osudu Žida vyrastajúceho v mad’arsko-slovenskom prostredí, ktorého životná skúsenost' bola výrazne ovplyvnená antisemitizmom a holokaustom. Štúdia sa chce zamerat’ na interpretáciu charakterov židovských hrdinov v Kadárovej tvorbe so zameraním sa na jeho tri filmové adaptácie - česko-slovenský film Obchod na korze (1965) podla predlohy Ladislava Grosmana, americkú snímku Angel Levine (1970) podla poviedky Bernarda Malamuda a kanadský film Lies my Father Told Me [Čo mi otec naklamal], ktorý vznikol na základe poviedky Teda Allana. Okrem komparácie spomínaných filmových adaptácií s ich literárnymi predlohami sa práca bude venovat' aj Kadárovmu odkazu pre súčasnú filmovú tvorbu a súčasné publikum.

\section{Kl'účové slová}

Ján Kadár; filmový režisér; židovskí hrdinovia; multikultúrna spoločnost' 


\section{Introduction}

At first sight, the production of film director Ján Kadár looks quite heterogeneous in terms of genres. We can find ideological film with elements of comedy (Katka), propaganda drama (Únos [Kidnapped]), satirical musical comedy (Hudba z Marsu [Music from Mars]), historical dramas from war period (Smrt si ř riká Engelchen [Death Is Called Engelchen], Obchod na korze), social dramas from contemporary times (Tam na konečné, [At at the Terminus], Obžalovaný [Accused]) or fairytale comedy with satiric elements (Tři přání [Three Wishes]). Despite such heterogeneousness, in his films we can also observe some common motifs and favourite topics. Kadár often inserted his works in multicultural environments (mostly urban) and showed ethnic and cultural diversity, not only as generator of interpersonal conflicts but also as inspirational milieu. Kadár was fascinated by heterogeneous environments and focused on destinies of people from minority communities. This fact is narrowly connected with his personal destiny. He was of Jewish origin and grew up in a Slovak-Hungarian context. His life experiences were influenced by antisemitism and the Holocaust during World War 2 but also by the Communist totalitarian regime in Czechoslovakia.

Ján Kadár was born on 1 April 1918 in Budapest. He spent his early childhood in Rožňava, a city co-inhabited by Hungarian, German, Jewish, and Slovak communities. His father Rezsö (Rudolf) was from the Hungarian city of Miskolc. His mother Lujza Tyrolerová was from the Slovak city of Dolný Kubín. Both of them belonged to the non-orthodox Jewish community. Together with his parents, Kadár was forced to move on several occasions. ${ }^{1}$ This fact was a helpful education for him, because he met specific cultures and learned about diverse human and character types. At the same time, it compelled him to reflect about his personal identity. World War 2 was as significant in his life. In 1940, because of his Jewish origin, Kadár was deported to a work camp near Galanta, in the zone of Slovakia occupied by Hungary. Later on, he was transferred to the Hungarian city of Vác; and he managed to escape from prison only on Christmas Eve 1944. In that same year, both parents died in Auschwitz; and then also his sister died in the same concentration camp. Because of rude antisemitism Kadár lost his loved ones. This sad event triggered his interest for the tradition of his ancestors: "I was raised in an environment where I never felt my Jewishness neither in religious nor in national terms. I would dare to say that I didn't even know I am Jew until Hitler declared it."

1 In 1925, due to financial problems, the family of the lawyer Rudolf Kadár moved from Rožňava to Brezno, and later on to Modrý Kameň. In 1934, they lived in Senec and - two years later - in Guta (Kolárovo). Young Kadár studied at gymnasiums in Lučenec and Levice. In 1936, he started to study at Charles University (Faculty of Law) in Prague. In 1938, because of his increasing interest in film art, he registered for a feature film course at the School of Arts and Crafts in Bratislava.

2 MACEK, Václav: Ján Kadár. Bratislava: Slovenský filmový ústav, 2008, p. 24. Before the war, Kadár did not have any interest in Jewish religiousness. This fact is also proved by his school report in the Lučenec gymnasium from 1934, where Jewish religion was not at all one of his strong points. In 1935, he was admonished by the school director for "misbehaviour during the classes of Jewish religion" (ibidem, p. 16). 
The tragic war experiences significantly shaped even Kadár's political antifascist and left-wing opinions. ${ }^{3}$ His political engagement can be recorded since his very early documentary film production. In 1946 he produced documentary films having character of political propaganda: Sú osobne zodpovedni za zločiny proti l'udskosti! [They Are Personally Responsible for Crimes against Humanity!] and Sú osobne zodpovedni za zradu na národnom povstani [They Are Personally Responsible for a Betrayal of the National Uprising]. These works were an act of accusation against president Jozef Tiso and his supporters, as people who were directly responsible for the death of thousands and thousands of inhabitants and for the burning of many villages. The clip film named Sú osobne zodpovedni za zlociny proti ludskosti! shows authentic shots of victims in mass graves and desolate-looking Holocaust survivors in concentration camps, with frequent alternation of shots depicting the main representative people of war time Slovak Republic, notably president Jozef Tiso. Political left-wing and antifascist groups did approve these images, whereas the supporters of the previous regime were outraged by those scenes. Samuel Belluš, a representative of the Democratic Party and Mandated Official for Information, eventually decided not to authorise public viewing of such films.

\section{Jewish Heroes in Czechoslovak Films by Ján Kadár and Elmar Klos}

Within the frame of filmmaking concerning the topic of the holocaust, Ján Kadár explicitly conveyed his message through the famous film Obchod na korze (1965). In his earlier film co-directed with Elmar Klos Smrt'sa volá Engelchen (1963), based on a novel by Ladislav Mňačko, we do meet a heroine of Jewish origin. Her name is Marta and she is a spy. ${ }^{4}$ She became the fateful love companion of the central hero - Pavol, a partisan. In the director's film adaptation, she represents one of the most ambivalent characters. According to Hana Timková ${ }^{5}$ this character immediately appears as a woman featured by multiple contrasts. She is involved in a partisan group (femininity in contrast with masculinity); she comes from a small village, but she works in town; she is surrounded by luxury resulting from her function (small village - town / lower class - higher class); and as a Jewess she works for the Germans (Jewish - fascist). The most remarkable contrast in this film is the motif of Marta's physical sacrifice (corporality - spirituality). Within

3 During the post-war period, Kadár presented himself (through his works) as a left-wing oriented artist, faithful to the communist regime. He directed the first Slovak communist propagandistic film Katka and - later on - together with Elmar Klos - Únos [Kidnapped] (1952), a classic example of the pro-soviet and pro-communist film propaganda at the beginning of the 1950's. Nevertheless, starting from the 2nd half of the 1950's, he became more and more critical against dehumanisation of politics in socialist Czechoslovakia (e.g. in the films Tam na konečné [At at the Terminus], Tři přani [Three Wishes], and Obžalovaný [Accused]).

4 It is important to note that her origin is mentioned only once during the film - and in an indirect way.

5 TIMKOVÁ, Hana: Text v texte. Literárny text a jeho d’alšie presahy vo filmovej adaptácii románu Smrt si ř́ká Engelchen. In: TIMKO, Štefan (ed.): Česká literatúra a film. Nitra: FSŠ UKF, 2014, p. 156. 
the film, Marta's destiny is codified as a reference to the biblical character of Ruth. ${ }^{6}$ Ruth was a Moabite, permanently excluded from membership in the nation of Israel. Jozef Macko $^{7}$ sees in Marta's personal sacrifice and in her martyr fate a reference to another biblical character - Mary Magdalene.

Obchod na korze became the most popular and most successful film by Kadár at international level (co-directed with Elmar Klos). Its precursor was the short story Past [The Trap] by Ladislav Grosman, published in 1962 in the Czech magazine Plamen. It describes the tragic story of a poor carpenter named Tóno Brtko who became the aryanisator of an almost bankrupted small shop belonging to an old Jewish widow named Rozália Lautmannová at times of First Slovak Republic. Ladislav Grosman was a writer of Jewish origin, born in Humenné, and author of the literary model and co-author of the screenplay of the film Obchod na Korze. And this is what he wrote about his short story: "I reflected about what sometimes leads even a good man to malevolence. Is it really only avidity or subjective character features? I think that good and bad sides of human character are always implemented at a certain stage of social knowledge and conscience. Human beings are all in all adaptive creatures, with their pros and cons. The real story of the death of a frightened old woman from an unknown place in Eastern Slovakia was the basis of this film. It did not give way to any form of indignation. The cruel act of her neighbour did not outrage anybody."

Similarly to Ján Kadár, even in the production of Ladislav Grosman WW2 was an element that triggered interest in his Jewish identity. During the war, Ladislav Grosman was personally victim of antisemitic persecution. His parents and three siblings died in 1944 during the bombing of a railway station. Many of his stories concern the bitter destiny of the Jews during the years of the First Slovak Republic and they are localised in the milieu of a small town under the Vihorlat hill. This is what George Grosman declared about his father Ladislav: "My father was a Jew and his identity of Humenné inhabitant was as strong as his Jewish identity; probably before the war it was even stronger than his Jewish identity."

During WW2 Ján Kadár was also interned in a work camp because of his ethnic origin. His parents and his sister died in Auschwitz concentration camp. Thanks to Grosman's short story, Kadár found a matter that helped him settle with his past. "In my heart, that matter gave birth to such a crucial moment in my life that I am continuously returning to it." ${ }^{10}$ In 1966, in an interview published by the New York Herald Tribune, he confessed that Obchod na korze is the film that he feels as the closest to him. ${ }^{11}$ When we

6 Both the film and the literary model by Ladislav Mňačko include a quotation from the Book of Ruth.

7 MACKO, Jozef: Slovák na Barrandove, Francúz na Kolibe. In: MACEK, Václav (ed.): Slovenský hraný film 1946-1969. Bratislava: Slovenský filmový ústav/Národné kinematografické centrum, 1992, p. 120.

8 ŠMATLÁK, Martin: Česko-slovenské korzovanie (dejinami). In: Interpretácia a film. Bratislava: Asociácia slovenských filmových klubov/Slovenský filmový ústav, 2008, p. 89.

9 GETTING, Peter: Kým sa nakrúcal Obchod na korze, jeho autor plakal v šatni. In: Sme.sk, 3. 9. 2021. Available online: https://plus.sme.sk/c/22729895/kym-sa-nakrucal-obchodu-na-korze-jeho-autor-plakal-v-satni.html.

10 LIEHM, Antonín Jaroslav: Hovoři Kadár - Klos. Film a doba 11, 1965, no. 7, p. 377.

11 KADÁR, Ján: Not the Six Million but the One. New York Herald Tribune, 23. 1. 1969. Quoted from MIKUŠOVÁ, Monika: Obchod na korze. Booklet Blu-ray of the film Obchod na korze. Bratislava: Slovenský filmový ústav, 2020, p. 12. 
read Kadár's interpretation of the central thought of this art work, we notice his consonance with Grosman's creative aim: "Obchod na korze denounces Slovak fascism with all its peculiar provincialism and familiarity - with terrific consequences. It is narrated by using only two characters, but it concerns much wider circumstances. Thus, it can be referred to any kind of fascism. Although the film presents destinies of single individuals, in reality it is the representation of a prototype."12

Grosman's short story Past was mediated to Ján Kadár by Arnošt Lustig, a prominent Czech prose writer and screenwriter who dedicated his efforts to the theme of Holocaust. Lustig was an important representative of the so-called second wave of war-time prose, in the period after 1956. These authors focused on psychological analysis and on more intimate descriptions of the relationships between the heroes and war events. On the other hand, they were less interested in mere reports of war facts. Apart from Lustig, this prosaic wave is also represented by Czech authors like Ladislav Fuks, Josef Škvorecký, and Jan Otčenášek, and by Slovak authors like Rudolf Jašík, Alfonz Bednár, and Vladimír Mináč. This literary current manifestly emphasised shorter literary forms (short stories, novels). We can classify into it even Ladislav Grosman from the Slovak city of Humenné, who started to publish works in Slovak language in 1955, but from 1958 wrote prevailingly in Czech language. Many of the above mentioned authors brought the topic of antisemitism and the Holocaust even to the filmmaking art, usually through film adaptations of their prose. The author who produced the highest number of film adaptations for his prose works was Arnošt Lustig. In 1961-1968, he operated as scriptwriter in the Prague film studio Barrandov. He worked on the creation of films like: Transport z ráje [Transport from Paradise] (1962), Démanty noci [Diamonds of the Night] (1964), Modlitba pro Kateřinu Horovitzovou [A Prayer for Kateřina Horovitzová] (1965), Dita Saxová (1967), and Colette (2013). Apart from the above mentioned films, the state antisemitism is admirably depicted for example in the film adaptation of a novel by Jan Otčenášek Romeo, Julie a tma [Romeo, Juliet, and Darkness], directed by Jiří Weiss in 1959. It describes the forbidden love story between Pavel (a gymnasium student) and Hanka (a Jewish woman) at the time of Protectorate. A similar topic of tragic love in the milieu of the first Slovak Republic is developed also in Jašík's novel Námestie svätej Alžbety [St Elisabeth Square] (1958). Its film adaptation by Vladimír Bahna in 1965 became the first explicit Slovak film about the Holocaust. ${ }^{13}$

With regard to intertext and intermedia transformation of the nine-page short story by Ladislav Grosman Past into a feature film (128 minutes), we can speak about complex continuity $^{14}$, but - as Ján Kadár noted - the original story does include only three scenes

12 Ibidem, p. 13.

13 Implicit references to the Holocaust appeared already in Slovak live-action films by director Peter Solan Boxer a smrt' [The Boxer and Death] (1962) and Organ (1964) by director Štefan Uher and screenwriter Alfonz Bednár. Source: TIMKO, Štefan: Perzekúcia židovského obyvatel'stva a holokaust v povojnovej slovenskej kinematografii. Slovenské divadlo 69, 2021, no. 2, p. 128-143.

14 The semiotician Tibor Žilka considers complex continuity to be the purest form of intertextuality connection of one text to another on the basis of the "one to one" principle. At the same time, he states that the plot of Obchod na korze is well developed and it is more compact than the original model. Source: 
of the film. ${ }^{15}$ In order to reach the length of a feature film, it was necessary to add something in the further stages of the screenplay preparation of the film - production of film story (text of 139 pages) and creation of literary and technical scenario. It was necessary to integrate existing motifs and to create new motifs. Therefore, in the whole adaptation process, the most frequently used creative approach was addition (i.e. enriching the original text with new scenes, elements, parts). ${ }^{16}$

In various interviews, co-directors Ján Kadár and Elmar Klos tended to present Grosman as the author of the subject or literary model (Past). Nevertheless, according to Grosman's wife, Edita, her husband went to see Kadár and brought him an already prepared and complete literary screenplay. ${ }^{17}$ The above reported words are also confirmed by material present in the Barrandov film studio archives. Here we can find the film story and the literary screenplay of Obchod na korze marked only with Grosman's name. Kadár and Klos completed Grosman's scenario and adapted it, by creating a technical screenplay. That's why they are officially mentioned as co-scriptwriters. Jana Ondrušová analysed and compared Grosman's literary screenplay with the technical script of Obchod na korze (and also with the final film). She concluded that - compared to the final film elaboration - Grosman's specific screenplay language is much more symbolic and it contains many analogies (notably inspired by animal motifs). ${ }^{18}$ The final film gives relatively little space to Brtko's wife (Evelína), whereas in the literary screenplay she is present in several places, with her private visions of future richness, incl. the relationship with a young Guard member.

Peculiar Grosman's humour was fully preserved in the film. Ján Kadár perceived the master model of Obchod na korze as a comedy in the ground plan of an ancient tragedy. ${ }^{19}$ Notably in the initial part of the film, humour is most remarkably generated by the tragicomic character of the carpenter Tóno Brtko, but a tragicomic portrait is also depicted in the character of the old Jewess Rozália Lautmannová. In 1966, in an article published by the literary magazine Slovenské pohlady, Emil Lehuta noted that the film creators saw the ethnic Jews 'only emotionally, generally in a compassionate way, even sentimental$\mathrm{ly}^{\prime 20}$. But it is not possible to completely agree with it. Similarly, another contradictory statement is that of Eva Vžentekováa ${ }^{1}$, when she declares that Lautmannová's character

ŽILKA, Tibor: Filmová adaptácia literárneho diela. In: TIMKO, Štefan (ed.): Literatúra a jej filmová podoba v stredoeurópskom kontexte. Nitra: UKF, 2020, p. 11-12.

15 LIEHM, Antonín Jaroslav: Hovoři Kadár - Klos. Film a doba 11, 1965, no. 7, p. 377. According to Elmar Klos, the story could inspire a twenty-minute short film. Kadár replied that there was enough material to produce ten feature films. Source: MACEK, Václav: Ján Kadár. Bratislava: Slovenský filmový ústav, 2008, p. 279.

16 ŽILKA, Tibor: Filmová adaptácia literárneho diela. In: Literatúra a jej filmová podoba v stredoeurópskom kontexte. Nitra: UKF, 2020, p. 14.

17 ONDRUŠOVÁ, Jana: Transformácia niektorých špecifických motívov Ladislava Grosmana vo vývojových fázach scenára Obchodu na korze. Brno: DIFA JAMU, 2017, p. 2.

18 Ibidem, p. 16.

19 LIEHM, Antonín Jaroslav: Hovoři Kadár - Klos. Film a doba 11, 1965, no. 7, p. 376-378.

20 MACEK, Václav: Ján Kadár. Bratislava: Slovenský filmový ústav, 2008, p. 160.

21 VŽENTEKOVÁ, Eva: Diptych Štefana Uhra Organ a Tri dcéry. Bratislava: FOTOFO - Stredoeurópsky dom fotografie, 2013, p. 194. 
eludes naturalism and it is depicted in a "melodramatic position". The character of old lady Lautmannová is far from that, of a melodramatic and sentimental heroine. In the context of the developed theme of persecution, she is a victim of unjust pressure and the public feels compassion for her. Her plastically portrayed character shows also comic or tragicomic moments. Because of Lautmannová's hearing loss and signs of senility, there are scenes of comic misunderstanding between the old lady and her aryanisator. E.g. in one scene the Jewish lady mispronounces Brtko's name and calls him Krtko [mole]. In some escalated situations, Lautmannová shows also domineering nature, rebellion, and anger at Tóno Brtko. Efforts of deheroing and humanisation of the central Jewish heroine are confirmed also by the memories of Juraj Herz, who worked as Kadár's assistant in the film Obchod na korze. The Polish actress of Jewish origin, Ida Kamińska, wanted to impersonate Lautmannová as a typical heroine, but Kadár told her: "No, you are not a heroine, don't forget it! You are an old senile Jewess in Eastern Slovakia!"22 The fact that the role of the old Jewish lady was assigned to an actress with Jewish origin can be considered as a further proof of Kadár's naturalistic approach. At the time of filming Obchod na korze this solution was quite unconventional in Czechoslovak cinematography. Indeed, the major trend was rather that of suppressing the differences between Jews and members of the majority society.

Kadár and Klos shot their film Obchod na korze in the outdoor environment of the city of Sabinov (in Eastern Slovakia) with Slovak personnel and in Slovak language (or Šariš dialect) ${ }^{23}$, but the film as a whole was produced by the Czech studio Barrandov. In Slovakia, the film topic was not really appreciated by the political elite. Both Alexander Dubček and Gustáv Husák were against its release in cinemas. Politicians perceived Kadár's and Klos' drama as negation of the Slovak National Uprising, but their rejection also reflected historical problems of Slovaks with national self-reflection. According to Elmar Klos jr, ${ }^{24}$ this film (a Czech production) originated under the auspices of Antonín Novotný as a provocation against Slovaks, because Novotný didn't like them too much. The topic of deportations of Jews during the first Slovak Republic and collaboration of majority population with Nazi Germany is still today a sensitive theme; and Slovak cinematography treats it only seldom and cautiously. ${ }^{25}$

22 According to the documentary film Juraj Herz, from the cycle named Zlatá šedesátá [The Golden 1960's] (3/26), Czech Republic, 2009, directed by Martin Šulík.

23 Almost all preparation phases of the screenplay of Obchod na korze are in Czech language. Slovak dialogues first appear only in the technical scripts. Source: ONDRUŠOVÁ, Jana: Transformácia niektorých špecifických motívov Ladislava Grosmana vo vývojových fázach scenára Obchodu na korze. Brno: DIFA JAMU, 2017, p. 2.

24 According to an interview with Elmar Klos jr available on DVD Obchod na korze (2002, Bontonfilm).

25 So far, the film that most openly revealed the topic of antisemitism during the first Slovak Republic is the Czecho-Slovak-American film Nedodržaný slub [Broken Promise] by the Czech director Jiří Chlumský (2009). Its incept are the memories of a Jewish sportsman Martin Friedmann at times of the first Slovak Republic. 


\section{Jewish Heroes in American and Canadian Films by Director Ján Kadár}

International prizes and - above all - the Oscar award for Obchod na korze paved the way for Ján Kadár's career in the USA. The first solely American Kadár's film was Angel Levine (1970), based on a story written in 1955 by Bernard Malamud, an American writer of Jewish origin. The screenplay of this film adaptation was prepared by Bill Gunn and Ronald Ribman. It describes the character of a Jew from New York named Mishkin (in master model: Manischevitz) who found himself in a critical life situation. A fire destroyed his tailor's business; his son was killed in the war; and he is not in contact with his daughter. He has physical problems and he is not able to work; and - moreover - his wife Fanny is dying. In such a hopeless state, an African American man called Levine comes and visits him and he presents himself as a Jewish guardian angel. He invites Mishkin to trust him and he is allegedly able to solve his basic troubles. Nevertheless, in the figure of Angel Levine Mishkin recognises a man who recently died in a robbery attempt. Kadár chose two social outsiders to play the roles of representatives of ethnic minorities (Mishkin and Levine). In the main part of the film, Levine becomes an even more tragic hero. He is a former criminal and he longs for Mishkin's acknowledgement. Indeed, Mishkin is a member of a minority that was back then much more accepted than the African American minority. The film also shows a negative hero, Harry Belafonte, an archetypal criminal (in the mind of the then dominating American society) who makes efforts to get rid of his sins in order to receive God's grace. The film clearly describes the idea of mutual tolerance and understanding for people who are affected by the stigma of prejudices. By presenting their destinies, the author remarks on the fact that none of us is without mistakes and without sins. Every one of us could get in trouble and fall in disgrace and adversity.

The basic difference between the master model and the film version resides in the unravelling of the central storyline. In the story by Bernard Malamud, Manischevitz acknowledges that even a black man can be a black angel. His faith consequently heals his wife Fanny. In Kadár's film, Mishkin does not trust Levine, he curses God and His messenger, and poor Fanny dies. The solution adopted by Kadár appears more logical in the light of the psychological profile of the main protagonists and story development. Indeed, in the course of the story, Levine provides a relatively small number of opportunities for Mishkin to believe in his supernatural skills and in the efforts to change his character. Due to this shift, the film does not have the usual Hollywoodian happy-end scheme. It does not comply with the criteria of the back then respected "American dream", showing reciprocal tolerance and cohesion of various ethnic groups forming the American society. The director's modification of the master model caused significant damage in terms of commercial success, but Kadár defended his creative intent with the following words: "Basic mistrust prevents from taking steps ahead the ones towards the others; that's why the story ends tragically. Many people cannot accept it and they reproached me, because I infringed the ethnic balance of the story. The truth is that I was interested in the general human issue, beyond the borders of daily controversies. And at the end of the day, neither Jews nor black people were satisfied." 26 
The definition of Kadár's author's focus is influenced by his life experience with many ethnic and racial prejudices that he experienced both in Slovakia and - analogously - on the American continent. By the way, the epilogue of Angel Levine also transmits a humanistic message refusing the sceptic impression of the film. Mishkin walks round the black quarter of Harlem and a little black feather suddenly falls down from the sky. The tailor tries to take the feather, but he doesn't succeed in catching it. The tailor Mishkin is in a similar hopeless situation as Tóno Brtko in Obchod na korze. He understands that it is too late. He knows he missed his chance to help his neighbour.

In 1975, in Canada, Kadár directed another outstanding film describing Jewish urban community. The title of this film is Lies my Father Told Me. The film was based on an autobiographical story written by Ted Allan in 1949 (a Canadian writer of Jewish origin). It described the destinies of a Russian-Jewish family living in the outskirts of Montreal. The head of the household is grandpa Zaida who is a model for his grandson David. Both of them try to keep the tradition of collectors of old bottles and domestic waste. David's father is an unsuccessful entrepreneur who would like to integrate in the dominating Canadian society and doesn't acknowledge the activities of his father Zaida. Eventually, old Zaida passed away and David has to settle not only with his departing, but also with the loss of things that were connected with him (e.g. grandpa's horse) and the traditional culture he represented. Kadár's film talks about childhood and memories of romantic times that shall not return. ${ }^{27}$

The film script was drawn up by Ted Allan based on motifs occurring in his short story, but the final version was composed in cooperation with Ján Kadár. This is what Ján Kadár stated about this cooperation: "I told Allan I cannot make a film about him and his grandpa... I could make a film about the story of a grandfather and a little boy, about a family representing the experience of everybody - something I could identify with." 28 Many critics compared the resulting pictures to Fellini's memories of Rimini in his Amarcord. In it we can also find Kadár's reflection about his childhood and adolescence in a Jewish community in Slovakia whose physical traces were practically destroyed forever.

Compared to the original screenplay version by Ted Allan, the main motif of the final film is not the conflict between grandfather's profound faith and his secular son-in-law (who wanted to educated his son "without religious nonsense"). As a non-orthodox Jew from Rožňava, Kadár offers a version in which the most important element is represented by the core conflict between the grandfather and the young family because of want of money (which is caused by lack of skills of the son-in-law, and not by his atheism). According to Macek ${ }^{29}$, the film does not want to convince the spectators that it is ideal to live according to the Talmud, but that no culture is possible without moral continuity. In this film, we also find traditional Kadár's understanding for people from lower social classes, who are

26 MACEK, Václav: Ján Kadár. Bratislava: Slovenský filmový ústav, 2008, p. 194.

27 TIMKO, Štefan: Židovská tematika vo filmoch Jána Kadára. In: HRBÁCSEK, Magdaléna: Židovský kultúrny fenomén v stredoeurópskom kontexte. Nitra: UKF, 2016, p. 157-158.

28 MACEK, Václav: Ján Kadár. Bratislava: Slovenský filmový ústav, 2008, p. 294.

29 Ibidem, p. 213. 
often the defenders of morality and traditional values. Lies my Father Told Me became one of the most successful Canadian films of all time. It won the Golden Globe Award as the best foreign film; and Ted Allan received Oscar nomination for original screenplay.

The figure of the Jewish hero also appears in Kadár's TV monodrama Mandelstam's Witness, directed in 1975. An old widow (impersonated by Ida Kamińska) tells the story of her husband Osip Mandelstam, a famous Russian Jewish poet who died because of Stalin's purges. The central theme of this work is not the Jewish issue, but the topic of power abusing - which occurs in several Kadár's films.

\section{The Message of Kadár's Film Heroes}

Ján Kadár accurately chose the topics of his films even during the American exile. He refused screenplays with topics that were not close to him. Indeed, he did not accept the offer to draw up the screenplay of The Godfather (that later became one of the most popular cult films), because he said he didn't know anything about Mafia. ${ }^{30}$ Films like Angel Levine or Lies my Father Told Me are the proof of the fact that the film director significantly adapted the character of the literary templates or scripts, in order to make them closer and more compliant with his life attitudes. Kadár was manifestly fascinated by stories of people with whom he managed to identify himself (or with a life experience that was similar or close to his own life experience). In 1974 he shot a TV film named The Blue Hotel (from the series American short story). In this work, he portrayed the story of a Swedish migrant who is murdered by a random visitor in a hotel in a small American town. The film is a psychological thriller about pervasive fear and it features the period of late 19th century. By the way, through this film Kadár was able to describe even his personal feelings and experiences as an immigrant in the USA.

In the second half of the 20th century, Kadár started to focus on social outsiders in his films - usually people from lower social classes, often persecuted by ruling power. The topic of discrimination is a relevant motif in the last film by Kadár Freedom Road (1979), based on the homonymous best-seller by Howard Fast. The main hero is Gideon Jackson, a former slave from Virginia in the 1870's, who was elected as Senator.

Kadár's interest in the Jewish issue within his live-action film production started with his most successful film Obchod na korze. Thanks to his personal experience, he managed to convincingly portray not only Slovak Jews, but also the members of Jewish communities in the USA and Canada. Kadár avoided their idealisation. The Jewish outsiders in his films are often imperfect, defective, or sinners - e.g. Lautmannová has hearing impairment, she is senile and sometimes rebellious; the poor tailor Mishkin is not able to repress his racial prejudices. Kadár is also able to look at his heroes from a comic point of view. Lies My Father Told Me ironically depicts the ambitious father of the young protagonist named David. Grandpa Zaida is portrayed with kind-hearted humour. Kadár 
is aware of the fact that - thanks to humour, irony, or self-irony - he manages to make accessible the topics and messages of his films to a wider audience.

The Jewish heroes of his films can also be perceived as symbols of cultural diversity, which always had a deep tradition even in the Central-European context. Thanks to his personal life experience and through the nature of his artistic production, Ján Kadár is a product of such a multicultural environment. His sensitivity for culture diversity, his understanding for alternativeness, and his compassion for social outsiders defined him as an extraordinary author on global scale. Still today, in an epoch characterised by loss of interhuman tolerance, his works are extraordinarily relevant; and he is rightfully the subject to frequent researches and promotion.

\section{Literature}

GETTING, Peter: Kým sa nakrúcal Obchod na korze, jeho autor plakal v šatni. Sme.sk, 3. 9. 2021. Available online: https://plus.sme.sk/c/22729895/kym-sa-nakrucal-obchodu-na-korze-jeho-autor-plakal-v-satni.html.

LIEHM, Antonín Jaroslav: Hovoři Kadár - Klos. Film a doba 11, 1965, no. 7, p. 376-378.

MACEK, Václav: Ján Kadár. Bratislava: Slovenský filmový ústav, 2008. 360 p.

MACEK, Václav - PAŠTEKOVÁ, Jelena: Dejiny slovenskej kinematografie. Martin: Osveta, 1997. 599 p.

MACKO, Jozef: Slovák na Barrandove, Francúz na Kolibe. In: MACEK, Václav (ed.): Slovenský hraný film 1946-1969. Bratislava: Slovenský filmový ústav/Národné kinematografické centrum, 1992, p. 117-132.

MIKUŠOVÁ, Monika: Obchod na korze. Booklet Blu-ray of the film Obchod na korze. Bratislava: Slovenský filmový ústav, 2020, 103 p.

ONDRUŠOVÁ, Jana: Transformácia niektorých špecifických motívov Ladislava Grosmana vo vývojových fázach scenára Obchodu na korze. Brno: DIFA JAMU, 2017. 18 p. Available online: https://is.jamu. cz/publication/12443/ondrusova-transformacia.pdf.

ŠMATLÁK, Martin: Česko-slovenské korzovanie (dejinami). In: Interpretácia a film. Bratislava: ASFK/ SFÚ, 2008, p. 83-90.

TIMKO, Štefan: Židovská tematika vo filmoch Jána Kadára. In: HRBÁCSEK, Magdaléna (ed.): Židovský kultúrny fenomén v stredoeurópskom kontexte. Nitra: UKF, 2016, p. 151-162.

TIMKO, Štefan: Perzekúcia židovského obyvatelstva a holokaust v povojnovej slovenskej kinematografii. Slovenské divadlo 69, 2021, no. 2, p. 128-143.

TIMKOVÁ, Hana: Text v texte. Literárny text a jeho d’alšie presahy vo filmovej adaptácii románu Smrt si ř́ká Engelchen. In: TIMKO, Štefan (ed.): Česká literatúra a film. Nitra: FSŠ UKF, 2014, p. 148160.

VŽENTEKOVÁ, Eva: Diptych Štefana Uhra Organ a Tri dcéry. Bratislava: FOTOFO - Stredoeurópsky dom fotografie, 2013. $271 \mathrm{p}$.

ŽILKA, Tibor: Filmová adaptácia literárneho diela. In: TIMKO, Štefan (ed.): Literatúra a jej filmová podoba v stredoeurópskom kontexte. Nitra: UKF, 2020, p. 9-23. 


\section{Mgr. art. Štefan Timko, PhD.}

Institute of Languages and Cultures of Central Europe

Faculty of Central European Studies, Constantine the Philosopher University in Nitra

Dražovská 4, 94974 Nitra, Slovak Republic

stimko@ukf.sk 